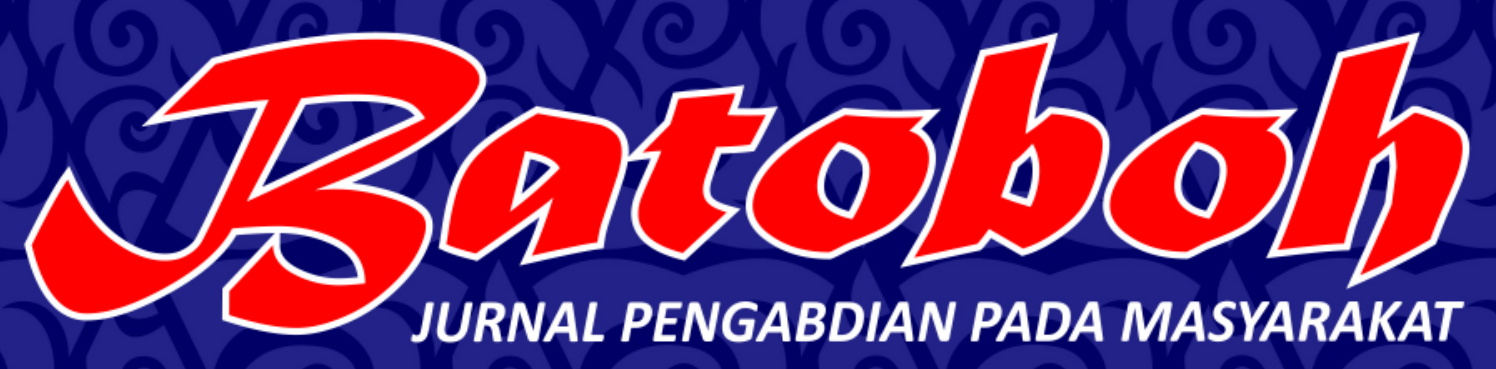

ISSN: 2548-5458

Volume 2,

Nomor 1,

April 2017

hIm. 1-65

Hartati, Martion, Mahdi Bahar

TARI ADOK MASYARAKAT PANINGGAHAN KABUPATEN SOLOK SEBAGAI SENI EKSPRESIF BUDAYA MINANGKABAU DALAM KONTEKS INDUSTRI KREATIF.

Yesriva Nursyam

PELATIHAN SENI TARI GUNA MENINGKATKAN WAWASAN DAN KETERAMPILAN GURU

SENI BUDAYA SMP SE-KAB. LIMA PULUH KOTA.

Desi Trisnawati, Ranelis, Wendra, Lucy Prasilia

PELATIHAN MEMBUAT TAS MAKRAME BAGI REMAJA PUTUS SEKOLAH DI UPTD BINA HARAPAN REMAJA PADANG PANJANG UNTUK MENUMBUHKAN MINAT BERWIRAUSAHA.

Armen Nazaruddin, Rica Rian, Nani Dian Sari, Ulan Dari

PENGEMBANGAN KREATIVITAS SISWA/I DAN GURU MIN LUBUAK MALAKO KECAMATAN SANGIR, KABUPATEN SOLOK SELATAN DENGAN MEMANFAATKAN MEDIA KALENG BEKAS.

Maria Erna Kustyawati, Sri Setyani, Ribut Sugiharto, Sri Waluyo PRODUKSI KOPI BUBUK TERINTEGRASI UNTUK MENINGKATKAN MUTU PADA KELOMPOK SERBA USAHA SRIKANDI DI KABUPATEN TANGGAMUS.

Aseptianova, Dini Afriansyah, Meli Astriani PENYULUHAN BAHAN MAKANAN YANG MENGANDUNG BORAKS DI KELURAHAN KEBUN BUNGA KOTA PALEMBANG. 


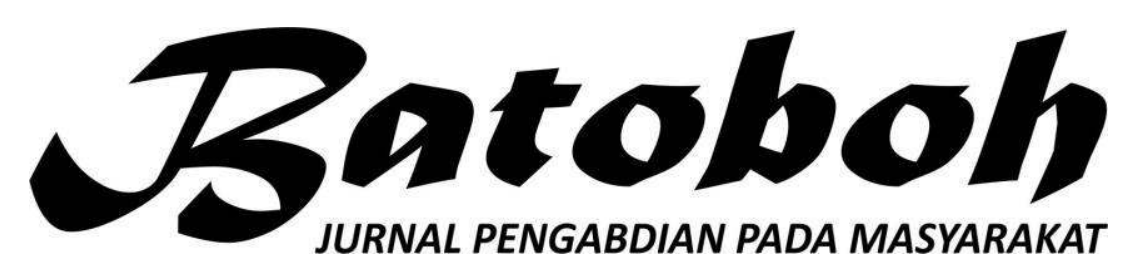

ISSN: 2548-5458 Volume2, Nomor 1, April 2017, hlm 1-65

Terbit dua kali setahun pada bulan April dan Oktober. Pengelola Jurnal Pengabdian pada Masyarakat menupakan subsistem LPPMPP Institut Seni Indonesia (ISI) Padangpanjang.

\author{
Proffireader \\ Novesar Jamanun \\ Febri Yulika \\ Editor In Chief \\ Andar Indra Sastra \\ Editors \\ Asril \\ Sahrul \\ RostaMinawati \\ Harissman \\ Manager Journal \\ Saaduddin \\ Liza Asriana \\ Rori Dolayance \\ Thegar Risky

\section{Editor Layout} \\ Yoni Sudiani \\ Administrator \\ Wira Dharma Prasetia
}

Alamat Pengelola Jurnal Batoboh:LPPMPP ISIPadangpanjang

Jalan Bahder Johan Padangpanjang 27128, Sumatera Barat; Telepon(0/52) 82077 Fax. 82803; e-mail; batoboh@gmail.com

Catatan. Isi/Materi jumal adalah tanggung jawab Penulis.

Diterbitkan Oleh

Institut Seni Indonesia (ISI) Padangpanjang 


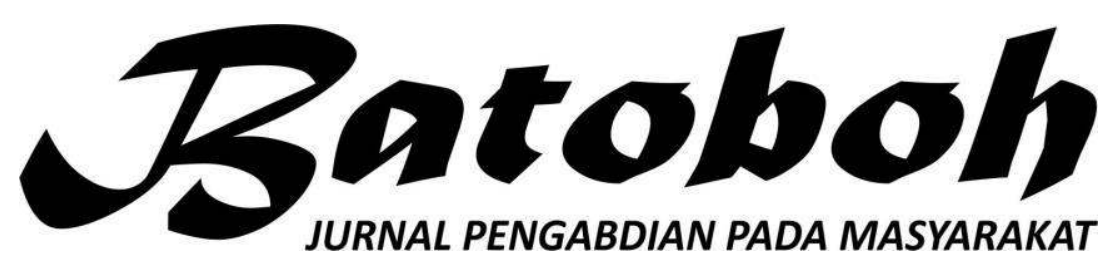

ISSN: 2548-5458 Volume2, Nomor 1, April 2017, hlm 1 - 65

\begin{tabular}{|c|c|c|}
\hline PENULIS & JUDUL & HALAMAN \\
\hline $\begin{array}{l}\text { Hartati } \\
\text { Martion, } \\
\text { Mahdi Bahar }\end{array}$ & $\begin{array}{l}\text { TARI ADOK MASYARAKAT PANINGGAHAN } \\
\text { KABUPATEN SOLOK } \\
\text { SEBAGAI SENI EKSPRESIF BUDAYA } \\
\text { MINANGKABAU } \\
\text { DALAM KONTEKS INDUSTRI KREATIF }\end{array}$ & 1-19 \\
\hline Yesriva Nursyam & $\begin{array}{llr}\text { PELATIHAN SENI } \quad \text { TARI } & \text { GUNA } \\
\text { MENINGKATKAN } \text { WAWASAN } & \text { DAN } \\
\text { KETERAMPILAN GURU SENI BUDAYA } & \text { SMP } \\
\text { SE-KAB. LIMA PULUH KOTA } & \end{array}$ & $20-29$ \\
\hline $\begin{array}{l}\text { Desi Trisnawati } \\
\text { Ranelis, Wendra } \\
\text { Lucy Prasilia }\end{array}$ & $\begin{array}{l}\text { PELATIHAN MEMBUAT TAS MAKRAME BAGI } \\
\text { REMAJA PUTUS SEKOLAH DI UPTD BINA } \\
\text { HARAPAN REMAJA PADANG PANJANG } \\
\text { UNTUK MENUMBUHKAN MINAT } \\
\text { BERWIRAUSAHA }\end{array}$ & 30-38 \\
\hline $\begin{array}{l}\text { Armen Nazaruddin } \\
\text { Rica Rian } \\
\text { Nani Dian Sari } \\
\text { Ulan Dari }\end{array}$ & $\begin{array}{l}\text { PENGEMBANGAN KREATIVITAS SISWA/I DAN } \\
\text { GURU MIN LUBUAK MALAKO KECAMATAN } \\
\text { SANGIR, KABUPATEN SOLOK SELATAN } \\
\text { DENGAN MEMANFAATKAN MEDIA KALENG } \\
\text { BEKAS }\end{array}$ & $39-44$ \\
\hline $\begin{array}{l}\text { Maria Erna Kustyawati, } \\
\text { Sri Setyani } \\
\text { Ribut Sugiharto } \\
\text { Sri Waluyo }\end{array}$ & \begin{tabular}{llll} 
PRODUKSI KOPI BUBUK & \multicolumn{2}{c}{ TERINTEGRASI } \\
UNTUK MENINGKATKAN & MUTU PADA \\
KELOMPOK & SERBA USAHA & SRIKANDI DI \\
KABUPATEN TANGGAMUS & &
\end{tabular} & $45-55$ \\
\hline $\begin{array}{l}\text { Aseptianova } \\
\text { Dini Afriansyah } \\
\text { Meli Astriani }\end{array}$ & $\begin{array}{l}\text { PENYULUHAN BAHAN MAKANAN YANG } \\
\text { MENGANDUNG BORAKS DI KELURAHAN } \\
\text { KEBUN BUNGA KOTA PALEMBANG }\end{array}$ & $56-65$ \\
\hline
\end{tabular}




\title{
PRODUKSI KOPI BUBUK TERINTEGRASI UNTUK MENINGKATKAN MUTU PADA KELOMPOK SERBA USAHA SRIKANDI DI KABUPATEN TANGGAMUS
}

\author{
Maria Erna Kustyawati, Sri Setyani, Ribut Sugiharto, Sri waluyo \\ Jurusan Teknologi Hasil Pertanian, Fakultas Pertanian Unila \\ Jurusan Teknologi Pertanian, Fakultas Pertanian Unila \\ Universitas Lampung, Jl. Sumantri Brojonegoro No. 1 Bandar Lampung \\ maria.erna@fp.unila.ac.id, \\ setyani@gmail.com \\ ributsugiharto@gmail.com
}

\begin{abstract}
ABSTRAK
Produk kopi bubuk yang diproduksi oleh Kelompok Serba Usaha (KSU) Srikandi Pekon Ngarip Kecamatan Ulu Belu Kabupaten Tanggamus dan Pemkab Tanggamus mempunyai kelemahan dalam hal warna, aroma serta rasa. Demikian juga harga yang masih rendah. Penyuluhan teknik tahapan produksi kopi bubuk dan pelatihan serta pendampingan untuk memperoleh PIRT dilakukan untuk meningkatkan mutu dan keamanan produk kopi bubuk. Target luaran yang ingin dicapai yaitu kopi bubuk dengan warna kayumanis, dan rasa khas kopi bubuk dengan harga meningkat 50\%. Metode pelaksanaannya dengan penyuluhan dan pelatihan dilanjutkan dengan pendampingan pada Kelompok Serba Usaha Srikandi pada lokasi dengan jarak lebih kurang 90 km dari Bandar Lampung. Hasil kegiatan menunjukkan bahwa 90\% anggota mitra melakukan pengolahan kopi beras sesuai tahapan dengan baik. Sebanyak $80 \%$ anggota melakukan praktek penyiapan dan pengolahan kopi bubuk secara higien. Perolehan PIRT masih $60 \%$. Keuntungan yang diperoleh dari penjualan produk (100g/kemasan) adalah $87,5 \%$. Dengan demikian peningkatan mutu dan pengemasan kopi bubuk telah tercapai. Usaha untuk memperoleh PIRT diperlukan lay out peralatan produksi di dalam rumah produksi yang sesuai dengan higienitas sehingga diperlukan rumah produksi yang sesuai.
\end{abstract}

Kata kunci: peningkatan mutu, kopi bubuk, KSU Srikandi, PIRT, rumah produksi. 
PENDAHULUAN

Salah satu penghasil kopi di Lampung yaitu Kabupaten Tanggamus. Di Kabupaten Tanggamus terdapat 20 Kecamatan penghasil kopi. Dinas Koperasi dan UKM, Perindustrian, Perdagangan dan Pengelolaan Pasar Kabupaten Tanggamus menyebutkan bahwa ada 40 Industri Kecil dan Menengah (IKM) kopi bubuk yang terletak di 8 Kecamatan yaitu Talang Padang, Gunung Alip, Ulu Belu, Air Naningan, Pulau Panggung, Limau, dan Wonosobo. Di daerah ini kopi bubuk diperoleh dari bahan baku kopi beras yang akan mempengaruhi kopi bubuk yang duihasilkan. Di daerah Tanggamus mempunyai wilayah seluas $\pm 285.546,00$ Ha yang di dalamnya terdapat kawasan hutan dengan luas $\pm 147.749,11 \mathrm{Ha}$ dan luas perkebunan seluas 85.924,65 Ha. Data statistik tahun 2015, khusus komoditi kopi Robusta luas 43.916,00 ha, produksi 27.581 ton. produktivitas $847,99(\mathrm{~kg} / \mathrm{ha})$ bentuk hasil biji kering asalan. Kecamatan Pulau Panggung Kabupaten Tanggamus mempunyai luas areal perkebunan kopi Robusta 7.339,00 ha dengan produksi $5.250,00$ ton/tahun atau produksi rata rata $879,25 \mathrm{~kg} / \mathrm{ha} /$ tahun. Sementara kecamatan Ulu Belu mempunyai luas areal perkebunan kopi Robusta 7.549,00 Ha dengan produksi rata rata $4.970,00$ ton/tahun atau $838,11 \mathrm{~kg} / \mathrm{ha} /$ tahun. Kabupaten Tanggamus memiliki kelompok tani pembuat kopi Robusta antara lain kelompok serba usaha (KSU) Srikandi di pekon Ngarip kecamatan Ulu Belu memproduksi kopi bubuk dengan merek Srikandi.

Kelompok usaha pengolahan kopi bubuk Srikandi mempunyai permasalahan pada proses penyangraian, penyosohan dan pengemasan serta perijinan. Bahan baku tidak seragam karena tidak dilakukan sortasi kopi beras. Alat penyangrai tidak mempunyai suhu pengontrol dan kapasitas kecil. Proses pengolahan belum higienis masih dilantai tanah, kopi yang telah disangrai diletakkan dalam nampan dilantai tanah, kopi bubuk dalam ember plastic, pegawai tidak higienis, dan alat pengemas manual. Pengolahan ini merupakan salah satu usaha untuk mempertahankan keberadaan kopi sesuai anjuran pemerintah propinsi Lampung. Kelompok usaha Srikandi melakukan produksi usaha kopi bubuk menggunakan peralatan yang dipinjam dari perorangan. Rumah tempat produksi juga masih menumpang di salah satu anggota kelompok. Belum mempunyai izin usaha. Oleh karena itu pengabdian kepada masyarakat sangat perlu dilakukan. Tujuan pengabdian adalah untuk meningkatkan mutu dan keamanan produk kopi bubuk dan untuk memperoleh PIRT dengan 
penyuluhan teknik tahapan produksi kopi bubuk, pelatihan dan pendampingan.

Propinsi Lampung merupakan penghasil tanaman kopi terutama jenis kopi Robusta. Tanaman kopi di Lampung pada umumnya milik petani yang luasnya rata-rata antara 0,5 -1,5 Ha. Berdasarkan data Statistik Lampung th 2009/2010 luas kebun kopi yang menghasilkan sebanyak 163.000 Ha dengan melibatkan petani kopi sebanyak 233.000 KK (Setyani et al., 2014). Sesuai program pemerintah dengan keputusan Gubernur Lampung no:G/346/B.IV/HK/2013 tentang perkopian, bahwa dalam rangka meningkatkan pendapatan masyarakat petani kopi, masih diperlukan penanganan dan pembinaan secara terpadu serta melakukan upaya mendorong terselenggaranya koordinasi insan perkopian dalam menjamin harga, mutu, dan produktivitas dibidang perkopian. Biji kopi merupakan bahan baku untuk dikonsumsi manusia, sehingga aspek mutu fisik, kimiawi, kontaminasi, dan kebersihan harus dijaga agar mempunyai rasa yang enak dan tidak membahayakan kesehatan. Mengingat manfaat kopi sebagai minuman penyegar yang bermanfaat bagi kesehatan dan bahkan pengobatan (Deddy, 2010). Sebagai minuman fungsional ini maka bubuk kopi harus memenuhi kriteria nilai gizi antara lain mengandung karbohidrat sekitar 52\%, lemak $14 \%$, protein $11 \%$, dan kavein $1,18 \%$ (Variyar et al., 2003). Sulistyowati (2002) dan Lin (2010) menyatakan bahwa pengolahan kopi yang kurang baik menimbulkan kerusakan citarasa seperti munculnya rasa asam, basi dan bau busuk. Pengolahan biji kopi dilakukan dengan cara (1) pengolahan kering, (2) pengolahan semi basah, dan (3) pengolahan basah. Pada umumnya petani melakukan proses pengolahan dengan cara kering yaitu panen buah masak, sortasi buah, pengeringan, pengupasan kulit, sortasi, pengeringan kembali, dan pengemasan (Natawidjaya, 2012). Tahapan proses pengolahan kopi ini menentukan mutu biji kopi dan kopi bubuk yang dihasilkan.

Mutu kopi beras atau biji kopi ditentukan menurut standar nasional Indonesia ( SNI 01-02907-2008) yang mencantumkan syarat mutu khusus untuk kopi Robusta dengan sistem defect system (nilai cacat). Nilai biji kopi juga ditentukan dari penampilan fisik, dan karakter citarasanya. Hasil penelitian ini akan memberikan manfaat terhadap perbaikan teknologi pengolahan kopi agar diperoleh kualitas kopi beras dan kopi bubuk yang baik. Dengan bahan baku dan proses pengolahan yang tepat, akan dihasilkan kualitas kopi beras dan kopi bubuk yang baik pula. Menurut Mulato (2001), kopi mengandung berbagai jenis 
senyawa, antara lain kafein, asam klorogenat, trigonelin, karbohidrat, lemak, asam amino, asam organik, aroma volatil, dan mineral. Menurut Variyar et al. (2003), asam klorogenat mempunyai aktivitas antibakteri, antiviral, dan antikanker dan kandungan kimia terbesar kopi sebagai antioksidan adalah asam klorogenat yang mempunyai titik leleh pada $208^{\circ} \mathrm{C}$ dan terdapat dalam kopi sebesar $4,5-11,1 \%$.

\section{PEMBAHASAN}

Pelaksanaan pengabdian berlangsung pada bulan April hingga November 2017 bertempat di Kelompok Serba Usaha Srikandi, di Pekon Ngarip, Kecamatan UluBelu Kabupaten Tanggamus, Provinsi Lampung. Kopi beras yang berasal dari anggota kelompok sebagai bahan utama dalam kegiatan pengabdian, dengan bahan-bahan penunjang antara laingas LPG dan bahan kemasaan.

Metode pelaksanaan kegiatan menggunakan (a) ceramah dan diskusi, mengenai pengolahan kopi beras dan pengolahan kopi bubuk, serta teknik pengemasan, kegiatan pelatihan/bimbingan dilaksanakan di rumah ketua kelompok tani dan salah satu pemilik kebun kopi, (c) pendampingan dan monitoring untuk mengetahui sejauh mana mitra telah melakukan usaha dan kendala yang dihadapi agar mendapat penyelesaian dengan baik.

\subsection{Sasaran strategis kegiatan}

Sasaran strategis kegiatan ini adalah petani kopi di kelompok serba usaha (KSU) Srikandi, dengan melibatkan penyuluh lapang dan tokoh masyarakat/kepala pekon sebagai pemandu. Untuk melihat keberhasilan kegiatan dilakukan evaluasi. Evaluasi efek dilakukan pada awal pelatihan (sebelum materi dijelaskan) dan di akhir pelatihan (setelah seluruh materi selesai dijelaskan), sedangkan evaluasi proses dilaksanakan pada akhir sessi dan evaluasi dampak penyelenggaraan dilakukan setelah kegiatan selesai. Penyediaan tempat dan fasilitas oleh mitra adalah rumah dan lahan usaha milik ketua Mitra, ibu Sri Wahyuni dan ibu Setyo.

\subsection{Evaluasi pelaksanaan kegiatan} Evaluasi pengetahuan dilakukan dengan metode pre test dan post test, pada setiap materi kegiatan. Tingkat pengetahuan peserta dikategorikan menjadi 3 yaitu: rendah (nilai <40), sedang $\quad(40<$ nilai $>75)$, tinggi $\quad(>75)$. Kegiatan ini dikategorikan berhasil apabila paling tidak $80 \%$ peserta mendapat nilai lebih dari 75. Selanjutnya evaluasi tahap 
akhir yang dijadikan tolok ukur pemberdayaan masyarakat tentang keberhasilan kegiatan pengabdian ini secara keseluruhan. Kegiatan pengabdian ini dikategorikan berhasil apabila paling sedikit $75 \%$ dari masyarakat petani kopi telah berhasil melakukan usaha dengan penerapan peralatan yang digunakan. Pembimbingan atau pendampingan dilakukan dengan mencari penyelesaian yang menjadi kendala para petani diantaranya dengan bantuan pengadaan peralatan pengolahan.

\subsection{Solusi dan target luaran}

Dari hasil pengamatan terhadap permasalahan yang terjadi pada mitra maka solusi yang ditawarkan adalah seperti pada Tabel 1.

Tabel 1. Matrik solusi dan target luaran

\begin{tabular}{|l|l|c|}
\hline Pengembangan & \multicolumn{1}{|c|}{ Ta } & Luaran \\
\hline $\begin{array}{l}\text { System } \\
\text { penyangraian }\end{array}$ & $\begin{array}{l}\text { Suhu dan } \\
\text { waktu } \\
\text { konsisten }\end{array}$ & $\begin{array}{c}\text { 80\% kopi } \\
\text { sangrai } \\
\text { berwarna }\end{array}$ \\
\hline $\begin{array}{l}\text { Tahapan } \\
\text { pengolahan } \\
\text { kopi bubuk }\end{array}$ & $\begin{array}{l}\text { Tahap } \\
\text { penyosoha } \\
\text { ner } \\
\text { dilakukan }\end{array}$ & $\begin{array}{c}\text { Kopi bubuk } \\
\text { berwarna } \\
\text { kayumanis } \\
\text { dengan rasa } \\
\text { khas kopi }\end{array}$ \\
\hline $\begin{array}{l}\text { System lay out } \\
\text { produksi }\end{array}$ & $\begin{array}{l}\text { Terwujudn } \\
\text { ya rumah } \\
\text { produksi }\end{array}$ & $\begin{array}{c}\text { Tata letak } \\
\text { peralatan } \\
\text { terintegrasi }\end{array}$ \\
\hline Manajemen & $\begin{array}{l}\text { Pengetahua } \\
\text { n mengenai } \\
\text { tatacara } \\
\text { kelola }\end{array}$ & \multicolumn{2}{|c|}{ PIRT } \\
\hline
\end{tabular}

Kelompok usaha Srikandi telah rutin memproduksi kopi bubuk 30 $\mathrm{kg} /$ minggu atau $500 \mathrm{~kg} / \mathrm{bulan}$. Bahan baku berasal dari anggota kelompok. Pengolahan kopi bubuk dilakukan oleh anggota dengan masing-masing pembagian tugas yang dikoordinir oleh coordinator yaitu Santi. Proses produksi kopi bubuk meliputi: penjemuran kopi gelondong di lantai tanah, buah kopi kering setelah penjemuran rata-rata 10 hari, kemudian dilakukan pelepasan kulit dalam mesi Huller, yang diletakkan kirakira $10 \mathrm{~m}$ dari rumah produksi. Kopi lepas kulit selanjutnya proses pencucian dan dijemur kembali sekedar untuk menghilangkan ai, dan masuk dalam mesin penyangrai berkapasitas $15 \mathrm{~kg}$, selama kurang lebih 15 menit karena suhu yang tidak terkontrol. Kopi sangrai dikering anginkan dalam tampak anyaman bamboo dan selanjutnya masuk dalam mesin penepung berkapasitas $5 \mathrm{~kg}$. oleh karena itu tahapan penyosohan perlu dilakukan untuk mencegah warna kopi bubuk lebih gelap, karena kult ari lebih cepat matang dibanding biji kopinya. Kopi bubuk ditampung dalam ember plastic, dan siap dikemas dalam plastic bermerek Srikandi kemudian di sealer secara manual. Proses produksi disajikan dalam Gambar 1. Kopi bubuk diproduksi dalam dua Grade yaitu Grade 1 Premium kopi 
bubuk tanpa campuran Rp 20,000/250g, Grade 1 Biasa, kopi bubuk dengan campuran beras (1:1) Rp. 10,000/250g, Rp 5000/125g dan Rp 1000/25g.

System pemasaran kopi bubuk hanya di sekitar desa dan mensuplay kebutuhan kopi bubuk karyawan Pertamina. Oleh karena itu perolehan ijin produksi PIRT perlu diupayakan untuk meningkatkan jangkauan pemasaran. Kelompok usaha memproduksi kopi bubuk sesuai dengan pemesanan yang antara lain jika pembeli adalah masyarakat di sekitar maka kopi bubuk nyaa adalah campuran kopi dengan beras (1:1). Kopi bubuk ini mempunyai warna gelap, dan disebut Grade 1. Konsumen Pertamina mengghendaki kualitas super atau premium yaitu $100 \%$ kopi. Oleh kaena itu produksi kopi bubuk baru sebatas pemesanan.

Proses penyangraian menggunakan alat sangrai berkapasitas $10 \mathrm{~kg}$ dan tidak mempunyai alat pengatur suhu. Hal ini mengakibatkan suhu dan waktu proses penyangraiian tidak konsisten dan hasilnya sangat bervariasi terutama warna, aroma, dan tentu saja kandungan senyawa gizi di dalamnya. Oleh karena itu tim pengabdian masyarakat memberikan bantuan alat penyangrai kopi biji beserta perlengkapannyaKSU Srikandi lengkap dengan alat pengatur suhu serta bahan bakar LPG.

Evaluasi pelaksanaan

Untuk mengetahui perkembangan dan pelaksanaan dilakukan 3 jenis yaitu evaluasi efek, evaluasi proses dan evaluasi penyelenggaraan/dampak . Evaluasi efek dilakukan pada awal pelatihan (sebelum materi dijelaskan) dan di akhir pelatihan (setelah seluruh materi selesai dijelaskan) untuk mengetahui daya serap peserta terhadap materi jang diberikan. Evaluasi proses dilaksanakan pada akhir sessi untuk melihat keberhasilan penyampaian materi, dan evaluasi penyelenggaraan/dampak dilakukan pada akhir seluruh kegiatan pelatihan. Tahapan yang dilakukan yaitu setelah penyampaian penyuluhan, dilakukan pelatihan/praktek, dan pemberian bantuan peralatan.

\section{Evaluasi Efek}

Penyampaian materi oleh tiga nara sumber berjalan dengan baik, didukung dengan bantuan alat LCD dan materi diperbanyak untuk mempermudah pemahaman peserta. Kegiatan ini dihadiri oleh 55 orang anggota petani kopi dari kelompok Lohjinawi dan Kelompok Tani Maju yang terdiri dari Bapak-bapak. Bentuk soal pada kuesioner awal dan akhir adalah sama seperti soal berikut:

Jawablah pertanyaan berikut dengan memilih YA atau TIDAK

1. Apakah saudara mengetahui tahapan 
pemetikan buah kopi (Ya/Tidak)

2. Apakah saudara mengetahui tahapan pasca panen buah kopi ( Ya/Tidak)

3. Apakah saudara mengetahui penerapan pengolahan kopi beras ( (Ya/Tidak)

4. Apakah saudara mengetahui cara penyimpanan dan pengemasan kopi yang baik (Ya/Tidak)

5. Apakah saudara mengetahui tata cara pengendalian kualitas /grading agar diperoleh kopi beras bermutu tinggi (Ya/Tidak)

6. Apakah saudara mengetahui pengolahan kopi bubuk yang baik (Ya/Tidak)

7. Apakah saudara mengetahui sanitasi pengolahan kopi bubuk ( Ya/Tidak)

8. Apakah saudara mengetahui manajemen usaha termasuk cara pemasaran kopi bubuk (Ya/Tidak). Rekapitulasi pre-test dan post-test terlihat pada Tabel 2.

Tabel 2. Rekapitulasi pre-test dan post-test

\begin{tabular}{|l|l|c|c|}
\hline No. & \multicolumn{1}{|c|}{$\begin{array}{c}\text { Hal yang } \\
\text { dievaluasi }\end{array}$} & $\begin{array}{c}\text { Pre-test } \\
\text { (\% peserta } \\
\text { yg } \\
\text { mengetahu } \\
\text { i) }\end{array}$ & $\begin{array}{c}\text { Post-test } \\
\text { (\% peserta } \\
\text { yg } \\
\text { mengetahu } \\
\text { i) }\end{array}$ \\
\hline 1 & $\begin{array}{l}\text { Pengetahuan } \\
\text { tahapan } \\
\text { pengolahan } \\
\text { kopi bubuk }\end{array}$ & 25 & 100 \\
\hline 2 & $\begin{array}{l}\text { Pengetahuan } \\
\text { tentang ijin } \\
\text { usaha PIRT }\end{array}$ & 20 & 89 \\
\hline 3 & $\begin{array}{l}\text { Pengetahuan } \\
\text { tentang } \\
\text { pengemasan }\end{array}$ & 66 & 100 \\
\hline 4 & $\begin{array}{l}\text { Pengetahuan } \\
\text { higienitas dan } \\
\text { sanitasi } \\
\text { selama proses } \\
\text { produksi kopi }\end{array}$ & 56 & 90 \\
\hline
\end{tabular}

\begin{tabular}{|l|l|c|c|}
\hline & bubuk. & & \\
\hline 5 & $\begin{array}{l}\text { Pengetahuan } \\
\text { pengawasan } \\
\text { mutu kopi } \\
\text { bubuk }\end{array}$ & 20 & 80 \\
\hline 6 & $\begin{array}{l}\text { Pengetahuan } \\
\text { manajemen } \\
\text { usaha kopi } \\
\text { bubuk }\end{array}$ & 53 & 87 \\
\hline 7 & $\begin{array}{l}\text { Pengetahuan } \\
\text { pemasaran } \\
\text { kopi bubuk }\end{array}$ & 20 & 80 \\
\hline & $\begin{array}{l}\text { Rata-rata \% } \\
\text { peserta yang } \\
\text { mengetahui }\end{array}$ & & 89,43 \\
\hline
\end{tabular}

Dari Tabel 2 terlihat bahwa setelah dilakukan penyuluhan, rata-rata peserta yang mengetahui materi yang disampaikan sebanyak $89,43 \%$. Hal ini mengindikasikan bahwa peserta telah memahami pengetahuan tentang penanganan pengolahan kopi, karena pesertanya adalah petani kopi itu sendiri yang telah melakukan pekerjaannya sebagai pekerjaan pokok, sehingga mereka antusias dengan diskusi yang hidup ditandai munculnya berbagai pertanyaan. Selain itu peningkatan pengetahuan juga karena adanya kontribusi dari pendamping lapangan dari seorang penyuluh perkebunan. Sementara materi perijinan PIRT beras merupakan materi yang baru, dan membutuhkan ketelitian dalam pengamatannya, sehingga persentasi peserta yang mengetahui materi lebih rendah daripada materi yang lain, kemungkinan pengaruh dari sumber daya manusia. Walaupun pemasaran merupakan materi yang tidak 
asing bagi peserta, namun mereka belum memahami teknik teknik pemsaran. Oleh karena itu nilainya juga rendah. Peserta ini rata-rata berumur 20-40 tahun dengan umur terendah umur 25 tahun dan paling tua 40 th, dengan rata-rata pendidikan lulusan SMA hingga Diploma.

\section{Evaluasi Proses}

Evaluasi proses bertujuan untuk menilai proses pelaksanaan kegiatan pelatihan pada tiap materi yang meliputi: kesesuaian materi dengan manfaat pelatihan, kemampuan instruktur dalam memahami daya serap peserta, penguasaan instruktur terhadap materi, keaktifan dan keseriusan peserta. Penilaian dilakukan dengan cara memberi skor 1-4 skala likert (Skala nilai : sangat kurang nilai 1 , kurang baik nilai 2 , baik nilai 3 , sangat baik nilai 4). Hasil evaluasi proses tehadap manfaat pelatihan, metode, materi, instruktur dan keaktifan serta keseriusan pesera pada pelatihan dapat dilihat pada Tabel 3. Dari Tabel 3 terlihat bahwa evaluasi pelaksanaan kegiatan penyuluhan/pelatihan pada tiap materi yang menyangkut proses dan kemanfaatan materi tehadap manfaat pelatihan, metode, materi, instruktur dan keaktifan serta keseriusan diperoleh rata-rata rentang nilai skor antara 3,54 sampai 3,76 yaitu antara baik dan sangat baik.

Hasil evaluasi pada Tabel 3, dari segi materi pelatihan secara berurutan tertinggi 3.76 pada materi Teknologi Pengolahan Kopi Bubuk, kemudian diikuti Pengemasan, Sanitasi kopi bubuk dan Managemen pemasaran yaitu masingmasing mendapatakan nilai $3.75 ; 3,59$ dan 3,56. Seperti diketahui usaha kopi yang diperoleh dari penanaman kopi dimulai sejak nenek moyang. Oleh karena itu mereka sudah mengetahui tentang pasca panen kopi hingga pengolahan menjadi kopi bubuk walaupun tanpa adanya penyuluhan. Tanamaman kopi dibiarkan tanpa pemeliharaan dan pengelolaanpun dapat tumbuh dan berproduksi walaupun tidak maksimal. Hal ini mengindikasikan bahwa peserta telah memahami pengetahuan tentang penanganan pengolahan kopi, karena pesertanya adalah petani kopi itu sendiri yang telah melakukan pekerjaannya sebagai pekerjaan pokok.

Tabel 3. Hasil evaluasi proses tehadap manfaat pelatihan, materi, instruktur dan

\begin{tabular}{|c|c|c|c|c|c|c|}
\hline \multirow[b]{2}{*}{ No } & \multirow[b]{2}{*}{ Materi Pelatihan } & \multicolumn{5}{|c|}{ Rataan } \\
\hline & & $\mathbf{a}$ & b & c & d & $\begin{array}{l}\text { Rata- } \\
\text { rata }\end{array}$ \\
\hline 1 & $\begin{array}{l}\text { Manajemen usaha } \\
\text { kelompok dan } \\
\text { Pemasaran }\end{array}$ & 3.65 & 3.75 & 3.50 & 3.35 & 3.56 \\
\hline 2 & $\begin{array}{l}\text { Pengolahan kopi } \\
\text { bubuk }\end{array}$ & 3.8 & 3.5 & 3.6 & 3.9 & 3.76 \\
\hline 3 & $\begin{array}{ll}\text { Sanitasi } & \text { Kopi } \\
\text { Bubuk } & \end{array}$ & 3.55 & 3.60 & 3.65 & 3.55 & 3.59 \\
\hline 4 & Pengemasan & 3.85 & 3.65 & 3.80 & 3.70 & 3.75 \\
\hline 5 & PIRT & 3.62 & 3.52 & 3.60 & 3.43 & 3.54 \\
\hline & Rata-rata & & & & & 3.66 \\
\hline
\end{tabular}


Keterangan: a)Kesesuaian materi dengan manfaat pelatihan, b)Kemampuan instruktur dalam memahami daya serap peserta, c)Penguasaan instruktur terhadap materi, d)Keaktifan dan keseriusan peserta

Oleh karena itu, mereka antusias dengan diskusi yang hidup ditandai munculnya berbagai pertanyaan. Selain itu peningkatan pengetahuan juga karena adanya kontribusi dari pendamping lapangan dari seorang penyuluh Dinas UMKM. Sementara materi PIRT merupakan materi yang baru, dan membutuhkan ketelitian dalam pengamatannya, sehingga persentasi peserta yang mengetahui materi lebih rendah daripada materi yang lain, karena mungkin belum pernah ada sosialisasi mengenai hal ini.

Evaluasi penyelenggaraan/Dampak.

Evaluasi dampak ini melihat perubahan Perkembangan industri rumah tangga kopi bubuk sangat menggembirakan. Pembuatan kopi bubuk sebelumnya untuk keperluan konsumsi sendiri, maka saat ini terlihat mulai diusahkan dengan melibatkan tenaga ibuibu rumah tangga. Adanya pengolahan kopi bubuk ini dapat memberdayakan tenaga wanita dalam proses penyangraian. Dalam $1 \mathrm{~kg}$ penyangraian kopi diperlukan waktu sekitar 30 menit. Kopi bubuk dipasarkan dengan harga di tingkat petani sebesar Rp80.000,-dan harga eceran di warung Rp 100.000,- per kg kopi bubuk. Pemasaran kopi bubuk ini tidak menjadi kendala, karena letak produsen dipinggir jalan utama dan pembeli dari pasar datang untuk membeli dalam skala besar, kemudian mereka menjual lagi di pasar tradisional terdekat seperti pasar Talang Padang. Dengan demikian usaha tambahan ini telah memperoleh nilai tambah yang nyata yang dapat meningkatkan pendapatan petani kopi. Jika menjual kopi bubuk premium sebelum perbaikan penyangraian dengan harga $\mathrm{Rp} 80,000 / \mathrm{kg}$ sedangkan dengan penrbaikan penyangraian kopi bubuk premium harga meningkat menjadi Rp 150.000,- /kg. Hal ini menandakan bahwa kelompok tani antusias untuk mengembangkan usahanya agar pendapatan dan kesejahteraan petani kopi meningkat.

Analisis Usaha

Modal Investasi

\begin{tabular}{|l|l|l|l|}
\hline No & \multicolumn{1}{|c|}{ Jenis alat } & Harga (Rp) & $\begin{array}{c}\text { Nilai } \\
\text { susut (10 } \\
\text { tahun }) \\
(\mathrm{Rp})\end{array}$ \\
\hline 1 & Mesin penggiling & 25000000 & 2500000 \\
\hline 2 & Mesin sangrai & 25000000 & 2500000 \\
\hline 3 & $\begin{array}{l}\text { Bahan Baku kopi } \\
\text { beras 1000 kg }\end{array}$ & $50000(\mathrm{~kg})$ & 50000000 \\
\hline 4 & Mesin pendingin & 10000000 & 1000000 \\
\hline 5 & Bahan Pengemas & 10000000 & 1000000 \\
\hline 6 & Mesin pengemas & 15000000 & 15000000 \\
\hline & Total Modal & \multicolumn{2}{|c}{} \\
\hline
\end{tabular}


Penjualan

\begin{tabular}{|l|l|}
\hline Penjualan & Nilai (Rp) \\
\hline Rendemen (g) & 8000 \\
\hline Harga jual (100 & \\
g)/Rp & 15000 \\
Jumlah & 120.000 .000 \\
\hline
\end{tabular}

Tingkat keuntungan yang diperoleh

\begin{tabular}{|l|l|}
\hline Keuntungan & \\
\hline Harga jual (Rp) & 120.000 .000 \\
\hline Modal (Rp) & 71.000 .000 \\
\hline Keuntungan (Rp) & 49.000 .000 \\
\hline
\end{tabular}

Dengan melakukan perbaikan pada proses penyangraian kopi beras maka penjualan kopi bubuk kualitas prima diperoleh keuntungan Rp. 49.000 .000 atau 87,5\%.

\section{SIMPULAN}

Sebanyak $80 \%$ anggota melakukan praktek penyiapan dan pengolahan kopi bubuk secara higien. Perolehan PIRT masih 60\%. Keuntungan yang diperoleh dari penjualan produk $(100 \mathrm{~g} / \mathrm{kemasan})$ adalah 87,5\%. Dengan demikian peningkatan mutu dan pengemasan kopi bubuk telah tercapai. Usaha untuk memperoleh PIRT diperlukan lay out peralatan produksi di dalam rumah produksi yang sesuai dengan higienitas sehingga diperlukan rumah produksi yang sesuai. Perlu disarankan untuk pemusatan alat alat produksi terintegrasi di dalam suatu rumah produksi agar terjaga higienitas dan sanitise. Perbaikan kemasan yang lebih menarik. Perlu pembinaan dalam teknik pemasaran misalnya melalui media internet.

\section{KEPUSTAKAAN}

Deddy. 2010. Manfaat Kopi untuk Kesehatan. http://www.mediainfoonline.com/in dex.php?option=com_content $\&$ view =article\&id=307:manfaat-kopiuntukkesehatan\&catid=40:kesehatan\&Ite mid=71. Diakses pada tanggal 25 Agustus 2016.

Prasetyo, H. 2011. http://hprasetyo.blogspot.com/2010/01/stan dar-mutu-kopi.html diakses pada tanggal 16 Maret 2016.

Lin, C. C. 2010. Approach of improving coffee industry in taiwan promote quality of coffee bean by fermentation. J. International Management Studies. 5 (1): 154159.

Natawidjaya, H. 2012. Pedoman Teknis Penanganan Pascapanen Kopi. Direktorat Pascapanen dan Pembinaan Usaha. Direktorat Jenderal Perkebunan. Kementrian Perkebunan. Hlm. 13-15.

SNI-01-3542-2004. Tahun 2004. Kopi Bubuk. Badan Standar Nasional.

Setyani, S., Susilawati, Zuidar S. 2014. IbM Kopi Pekon Way Harong Kecamatan Air Naningan Kabupaten Tanggamus. Lembaga Penelitian dan Pengabdian Kepada Masyarakat. Universitas Lampung. Sulistyowati. 2002. Faktor-Faktor yang Berpengaruh Terhadap Citarasa 
Seduhan Kopi. Materi Pelatihan

Uji Citarasa Kopi. Pusat Penelitian Kopi dan Kakao, Jember. 17. 138148.

Variyar, P.S., R. Ahmad, R. Bhat, Z. Niyas, dan A. Sharma. 2003. Flavoring components of raw monsooned arabica coffee and their changes during radiation processing. J. Agric. Food Chem. 51(27): 7945-50.

\section{LAMPIRAN}

\section{Kegiatan Pengabdian}

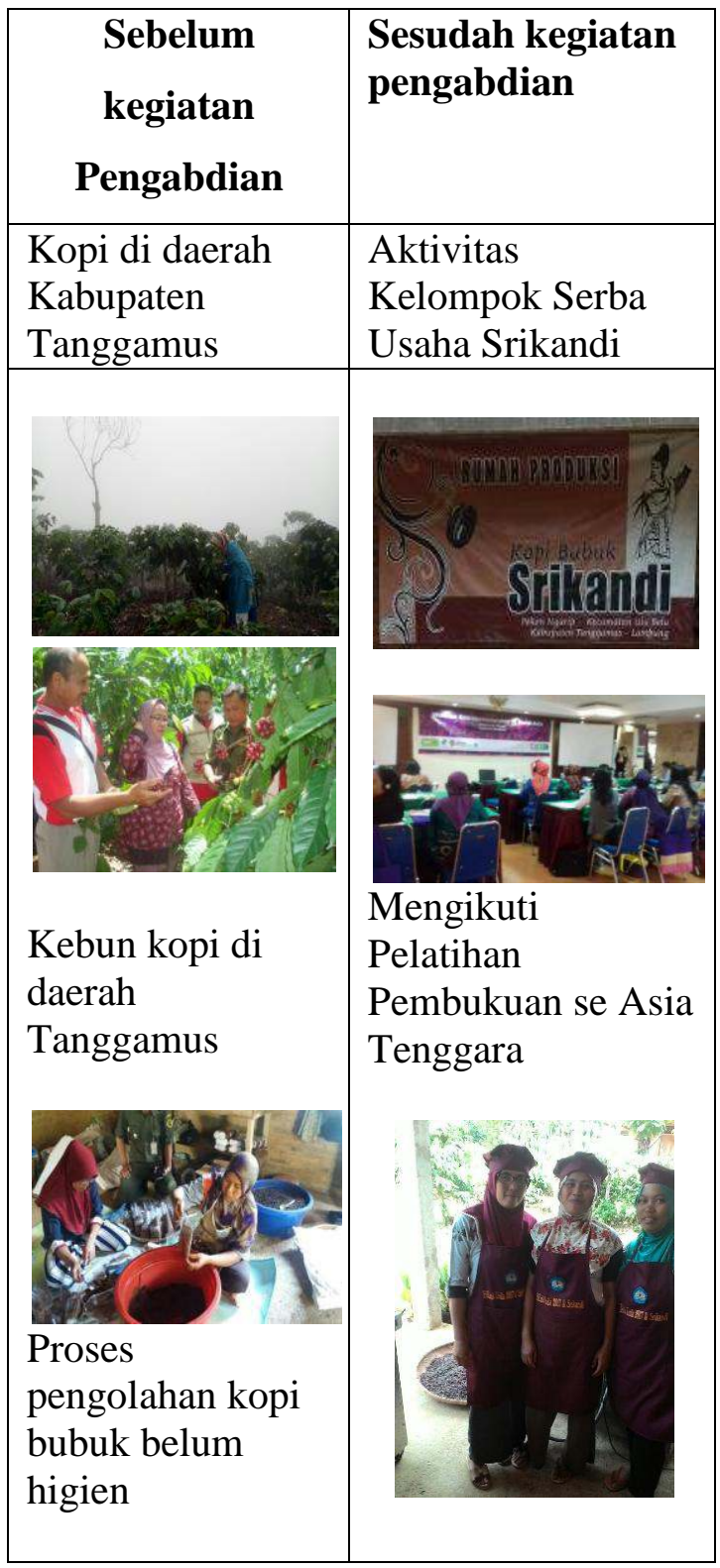


Jurnal Batoboh, Vol. 2, No. 1, April 2017

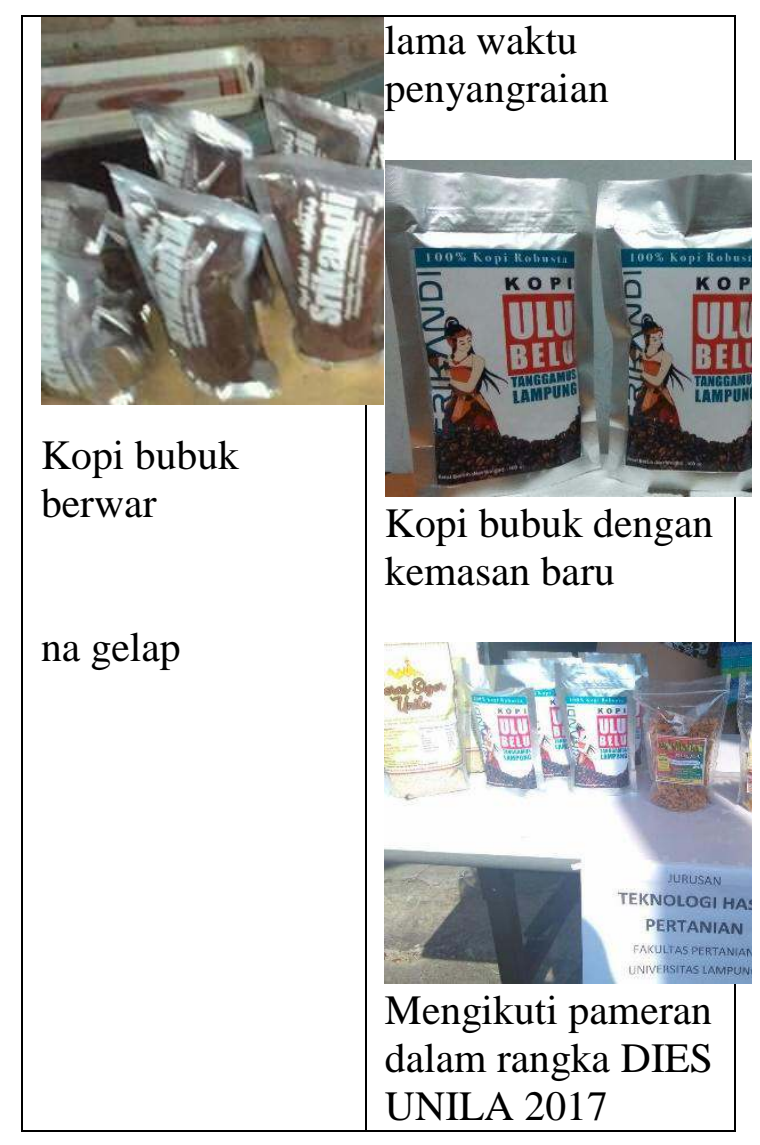


FILOSOFI "BATOBOH":

Dalam masyarakat Minangkabau upacara-upacara yang dilakukan sebelum mendirikan bangunan baik Rumah Gadang maupun Balairung (Balai Adat) serta bangunan lainnya yang dikenal dengan beberapa upacara yang disebut dengan batoboh. Batoboh berasal dari kata Taboh yang artinya menebang atau mengambil sesuatu, jadi dengan mengambil kayu dihutan sebagai bahan utama dalam membangun rumah dan bangunan lainnya. Upacara Batoboh ini sangat bermanfaat bagi masyarakat Minangkabau yaitu dapat meningkatkan Gotong-Royong dan solidaritas antar sesama suku Minangkabau karena memberi kesempatan kepada kerabat-kerabat untuk terlibat dalam pembangunan rumah serta bangunan lain.

Alamat Redaksi: LPPMPP ISI Padangpanjang Jalan Bahder Johan Padangpanjang 27128 Sumatera Barat Telp. (0752) 485466, Fax.(0752) 82803 e-mail: batoboh@gmail.com

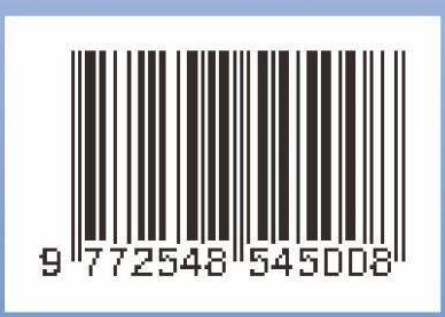

